\title{
Interhemispheric coupling, the West Antarctic Ice Sheet and warm Antarctic interglacials
}

\author{
P. B. Holden ${ }^{1}$, N. R. Edwards ${ }^{1}$, E. W. Wolff ${ }^{2}$, N. J. Lang ${ }^{2}$, J. S. Singarayer ${ }^{3}$, P. J. Valdes ${ }^{3}$, and T. F. Stocker ${ }^{4}$ \\ ${ }^{1}$ Earth and Environmental Sciences, Open University, Milton Keynes, UK \\ ${ }^{2}$ British Antarctic Survey, Cambridge, UK \\ ${ }^{3}$ School of Geographical Sciences, University of Bristol, Bristol, UK \\ ${ }^{4}$ Climate and Environmental Physics, University of Bern, Bern, Switzerland
}

Received: 27 November 2009 - Published in Clim. Past Discuss.: 17 December 2009

Revised: 6 July 2010 - Accepted: 7 July 2010 - Published: 16 July 2010

\begin{abstract}
Ice core evidence indicates that even though atmospheric $\mathrm{CO}_{2}$ concentrations did not exceed $\sim 300 \mathrm{ppm}$ at any point during the last 800000 years, East Antarctica was at least $\sim 3-4{ }^{\circ} \mathrm{C}$ warmer than preindustrial $\left(\mathrm{CO}_{2} \sim 280 \mathrm{ppm}\right)$ in each of the last four interglacials. During the previous three interglacials, this anomalous warming was short lived ( $\sim 3000$ years) and apparently occurred before the completion of Northern Hemisphere deglaciation. Hereafter, we refer to these periods as "Warmer than Present Transients" (WPTs). We present a series of experiments to investigate the impact of deglacial meltwater on the Atlantic Meridional Overturning Circulation (AMOC) and Antarctic temperature. It is well known that a slowed AMOC would increase southern sea surface temperature (SST) through the bipolar seesaw and observational data suggests that the AMOC remained weak throughout the terminations preceding WPTs, strengthening rapidly at a time which coincides closely with peak Antarctic temperature. We present two $800 \mathrm{kyr}$ transient simulations using the Intermediate Complexity model GENIE-1 which demonstrate that meltwater forcing generates transient southern warming that is consistent with the timing of WPTs, but is not sufficient (in this single parameterisation) to reproduce the magnitude of observed warmth. In order to investigate model and boundary condition uncertainty, we present three ensembles of transient GENIE-1 simulations across Termination II (135000 to $124000 \mathrm{BP}$ ) and three snapshot HadCM3 simulations at 130000 BP. Only with consideration of the possible feedback of West Antarctic Ice Sheet (WAIS) retreat does it become possible to simulate the magnitude of observed warming.
\end{abstract}

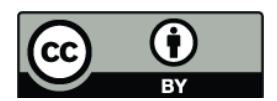

Correspondence to: P. B. Holden (p.b.holden@open.ac.uk)

\section{Introduction}

The AMOC transports a substantial amount of heat from south to north. If the AMOC is weakened through changes in surface buoyancy, Northern Atlantic cooling and Southern Atlantic warming is simulated in ocean models of various complexities (Stouffer et al., 2006). This effect, the bipolar seesaw, has been proposed (Stocker and Johnsen, 2003) to explain the interhemispheric teleconnection of abrupt millennial-scale shifts in glacial climate known as Dansgaard-Oeschger (DO) events (Dansgaard et al., 1993). We here address the proposed role of the bipolar seesaw in defining the characteristics of glacial terminations and the interglacials which follow them (Ganopolski and Roche, 2009; Masson-Delmotte et al., 2010).

Antarctic temperature (Jouzel et al., 2007) and atmospheric methane (Loulergue et al., 2008) are illustrated in Fig. 1a. Numerous paleorecords (Carlson, 2008) reveal that the most recent termination (TI) exhibited rapid transitions in Northern Hemisphere climate, in approximate anti-phase with change in Antarctica (Blunier et al., 1998). Antarctica warmed slowly from $\sim 18 \mathrm{kyr} B \mathrm{BP}$ to temperatures similar to preindustrial at $\sim 12 \mathrm{kyr} \mathrm{BP}$, interrupted by the Antarctic Cold Reversal (ACR) at $\sim 14 \mathrm{kyr} \mathrm{BP}$, a cooling event which has been interpreted as the southern analogue of the BøllingAllerød Northern Hemisphere warming, both manifestations of a temporary resumption of Atlantic overturning (Blunier et al., 1998; Barker et al., 2009). Rapid increases in methane provide a proxy for rapid increases in Greenland temperature (Delmotte et al., 2004) and hence, according to this interpretation, for the resumption of overturning.

Published by Copernicus Publications on behalf of the European Geosciences Union. 

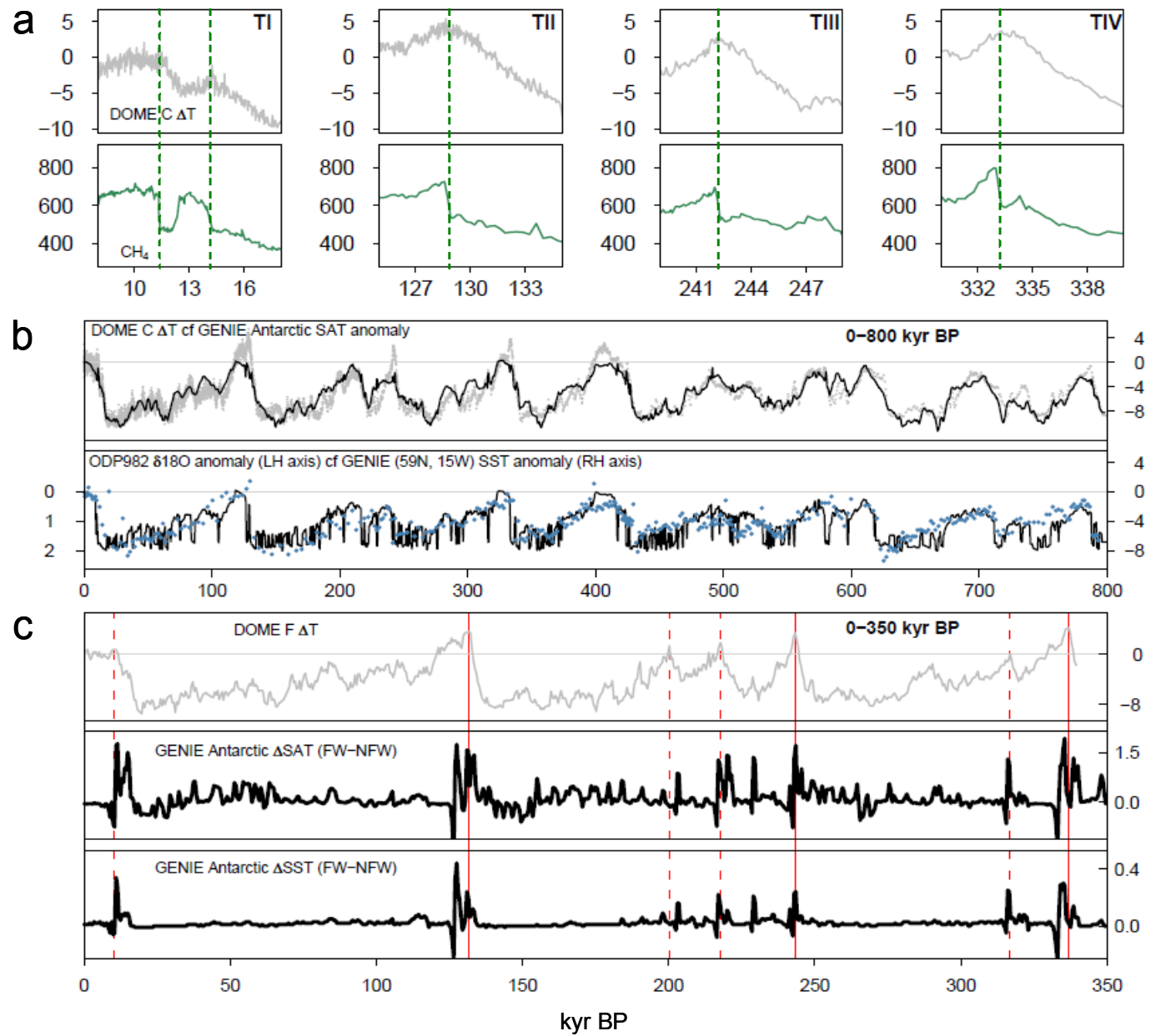

Fig. 1. (a) DOME C $\delta$ D-inferred Antarctic temperature anomaly (Jouzel et al., 2007) (grey) and atmospheric $\mathrm{CH}_{4}$ concentration (Loulergue et al., 2008) (green) at the last four terminations. (b) $800 \mathrm{kyr}$ records of DOME C Antarctic temperature anomaly (grey) and planktonic $\delta^{18} \mathrm{O}$ anomaly (blue) at ODP site $982\left(57.3^{\circ} \mathrm{N}, 15.5^{\circ} \mathrm{W}\right)$ (Venz et al., 1999), compared respectively with the GENIE-1 (GW) Antarctic SAT anomaly and the SST anomaly at the grid cell centred on $59^{\circ} \mathrm{N}, 15^{\circ} \mathrm{W}$. (c) $350 \mathrm{kyr}$ records of DOME F $\delta$ D-inferred Antarctic temperature anomaly (Kawamura et al., 2007) (grey), GENIE-1 meltwater-induced ( $\mathrm{G}_{\mathrm{FW}}-\mathrm{G}_{\mathrm{NFW}}$ ) Antarctic SAT and SST anomalies. SAT is averaged over Antarctica south of $71^{\circ} \mathrm{S}$. SST is averaged over all the Southern Ocean south of $62^{\circ} \mathrm{S}$. Note: the simulation in (b) includes meltwater forcing, but the effects in Antarctica (up to $\sim 1.5^{\circ} \mathrm{C}$ warming) are largely obscured by the larger changes across the terminations.

In contrast, the three previous terminations (TII, TIII and TIV) exhibit a behaviour that is quite distinct from TI, although they display remarkable similarities to one another. In each case a transient spike in Antarctic temperature (WPT) of up to $\sim 4^{\circ} \mathrm{C}$ lasting $\sim 3 \mathrm{kyr}$ is apparent at the start of the interglacial. Recent analysis (Sime et al., 2009) suggests that the isotopic composition of East Antarctic ice is less sensitive to temperature change in a warm climate, consistent with even higher peak Antarctic temperatures during these interglacials (at least $\sim 6^{\circ} \mathrm{C}$ warmer than present day), though this work did not consider the warming mechanism of the bipolar seesaw that is addressed here. Observational evidence for WPTs in Antarctica is not confined to ice-core records. Notably, a $430 \mathrm{kyr}$ Southern Ocean SST reconstruction (Cortese et al., 2007) at ODP site $1089\left(41^{\circ} \mathrm{S} 10^{\circ} \mathrm{E}\right)$ displayed transient warming during each of these terminations, lasting for $5-9 \mathrm{kyrs}$ and with temperatures 2 to $3.5^{\circ} \mathrm{C}$ warmer than present (in addition to a $\sim 2{ }^{\circ} \mathrm{C}$ transient warming lasting for $7 \mathrm{kyr}$ during TI). GCM simulations have thus far failed to produce a warmer Antarctica during the last interglacial (e.g. Montoya et al., 2000; Groll et al., 2005; OttoBliesner et al., 2006; Masson-Delmotte et al., 2010).

The second striking similarity between these earlier terminations is that the methane record does not exhibit the oscillatory behaviour that is apparent in TI, but rather displays a single rapid jump (vertical tie-bars in Fig. 1a) late in the termination (which we associate with a resumption of overturning). In each case this methane jump coincides closely with the peak in Antarctic temperature. Furthermore, each methane jump corresponds to an abrupt shift in Chinese 
speleothem $\delta^{18} \mathrm{O}$ (Wang et al., 2001; Cheng et al., 2006, 2009), a proxy for Asian Monsoon strength, which further suggests a role of the bipolar seesaw during terminations (Cheng et al., 2009). The "Weak Monsoon Intervals" (Cheng et al., 2009) which precede each of the methane shifts approximately coincide with peaks in ice rafted debris in the North Atlantic ODP 980 core (McManus et al., 1999), supporting the view that these changes were associated with disintegrating Northern Hemisphere ice sheets.

Recent climate model simulations have addressed this potential mechanism for early interglacial warmth. A simulation with the IPSL GCM which included a parameterisation of Greenland melt at $126 \mathrm{kyr}$ BP predicted year-round warming of $0.5^{\circ} \mathrm{C}$ in Antarctica, thus implicating the bipolar seesaw as a possible driver of transient warmth in MIS 5.5 (Masson-Delmotte et al., 2010). Ganopolski and Roche (2009) performed idealised transient experiments across a glacial termination with CLIMBER-2, an Intermediate Complexity model which includes a 2.5-D statistical-dynamical atmosphere model coupled to a zonally-averaged, threebasin ocean model. These simulations produced $\sim 2{ }^{\circ} \mathrm{C}$ transient Antarctic warming in response to $0.2 \mathrm{~Sv}$ freshwater flux into the North Atlantic and suggested that the qualitative differences between recent terminations may result from modest differences in the rate of deglaciation.

It has recently been suggested that the suppression of DO events (which would cool Antarctica) enables terminations to progress unchecked (Wolff et al., 2009). Here we propose, following Ganopolski and Roche (2009), that if the AMOC remains weakened throughout the termination the system will progress to a WPT state. Furthermore, we propose the WPT may eventually lead to partial collapse of the WAIS, leading to further warming. Thus although the radiative forcing due to Northern Hemisphere ice sheets and greenhouse gases was similar to preindustrial in the each of the last three interglacials, weakened overturning together with potential WAIS retreat lead to conditions in Antarctica during the early stages of these interglacials which were significantly warmer than modern. The resumption of overturning, associated with the cessation of deglaciation meltwater, subsequently cools Antarctica to conditions that are comparable to present day.

In order to examine the temporal history of Northern Hemisphere meltwater feedbacks on Antarctic climate, and evaluate the modelling and boundary condition uncertainty, we have performed three sets of experiments. The approach, building on Holden et al. (2010), is designed to allow for the uncertainty that arises from structural error, the irreducible error that remains when the "best" parameters are applied to a model (Rougier, 2007). The multi-millennial transient simulations required here can only be performed with an intermediate complexity model. We use GENIE-1 (Lenton et al., 2006), built around a low resolution $3 \mathrm{D}$ frictional geostrophic ocean model. An ensemble approach is essential to quantify modelling uncertainty that arises from structural limitations of such a model. Furthermore, we supplement the GENIE-1 ensembles with simulations using the Hadley centre coupled model HadCM3 (Gordon et al., 2000) in order to investigate robustness with respect to specific structural limitations, especially related to the lack of a dynamic atmosphere. The three experiments are:

i) Two transient $800 \mathrm{kyr}$ simulations with GENIE-1, one which includes the effects of glacial meltwater on ocean circulation and one which neglects this feedback. These simulations provide a long time-series comparison between observations and model results and allow a qualitative assessment of the role of meltwater in determining transient Northern Atlantic and Antarctic temperatures.

ii) Three ensembles of GENIE-1 transient simulations over glacial termination TII, applying the LGM Plausibility Constrained (LPC) parameter set which covers the range of large-scale feedback strength displayed by multi-model GCM ensembles (Holden et al., 2010). These ensembles enable quantification of both modelling and boundary condition uncertainties, including an evaluation of potential WAIS retreat feedbacks.

iii) Three equilibrium simulations with $\mathrm{HadCM} 3$ at $130000 \mathrm{BP}$, performed to investigate the robustness of the conclusions derived from GENIE-1, in particular with respect to its simplified atmosphere and snow models.

\section{Methods}

\subsection{GENIE-1}

The intermediate complexity model GENIE-1 has been extensively applied to investigations of the thermohaline circulation (Marsh et al., 2004) and provides the computational efficiency required to perform large ensembles and quantify model uncertainty. The physical model comprises a 3-D frictional geostrophic ocean with eddy-induced and isopycnal mixing coupled to a 2-D fixed wind-field EnergyMoisture Balance Model (EMBM) atmosphere and a dynamic and thermodynamic sea-ice component (Edwards and Marsh, 2005). These are coupled to a minimum spatial model of vegetation carbon, soil carbon and soil water storage (Williamson et al., 2006). The model configuration is as described in Lenton et al. (2006), with adjustments to the parameterisation of outgoing longwave radiation (OLR) applied in the ensemble experiments and the inclusion of orography feedbacks for surface processes (applied throughout). The adjustment to the OLR parameterisation is designed to allow for uncertainties in cloud and lapse rate feedbacks. Both changes are detailed in Holden et al. (2010). 

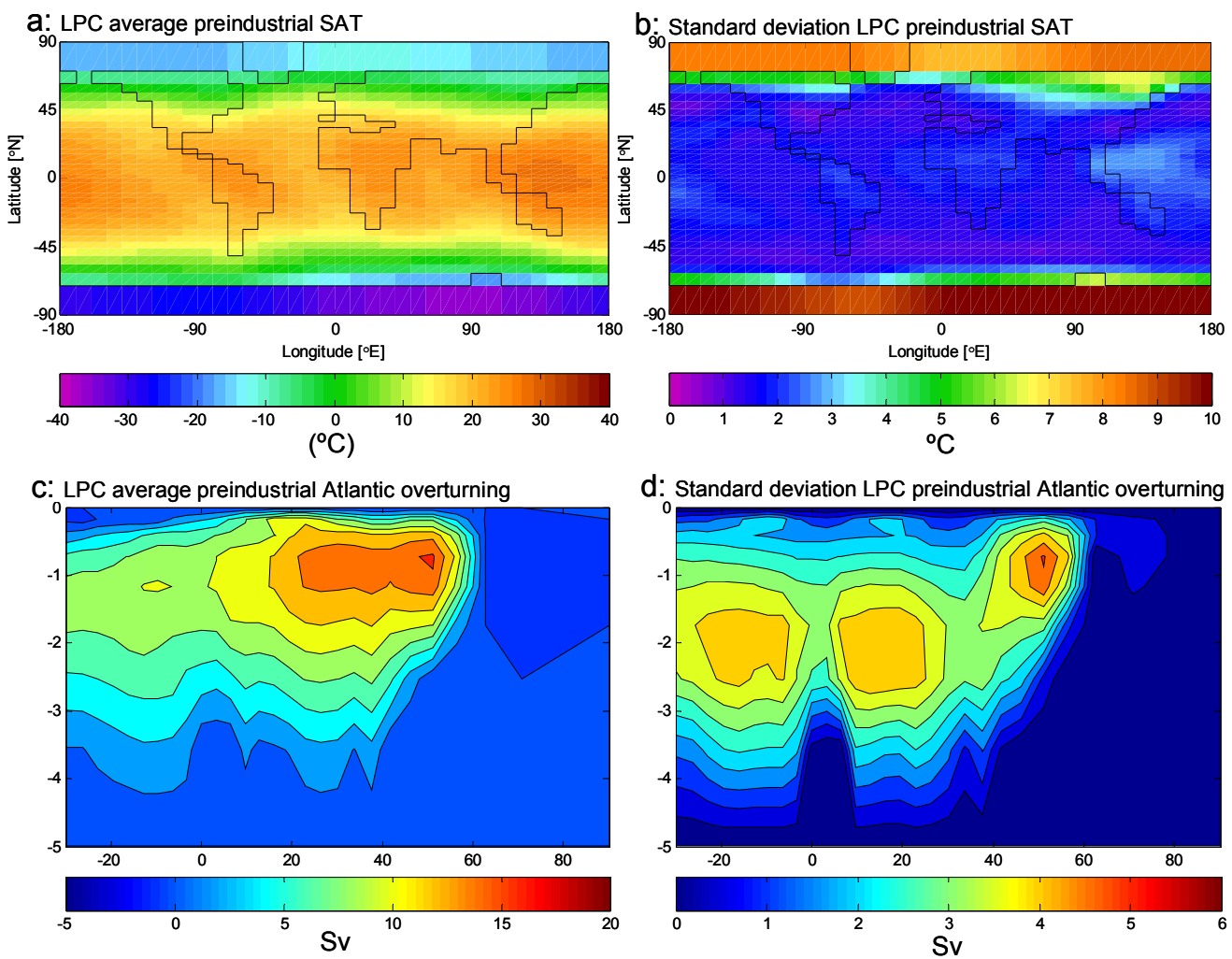

Fig. 2. Ensemble average and standard deviation of preindustrial $(\mathbf{a}, \mathbf{b}) \mathrm{SAT}\left({ }^{\circ} \mathrm{C}\right)$ and $(\mathbf{c}, \mathbf{d})$ Atlantic overturning stream function $(\mathrm{Sv})$. Data are derived from the LPC (LGM Plausibility Constrained) parameter set (Holden et al., 2010).

The $800 \mathrm{kyr}$ simulations (experimental set-up described in Sect. 2.1.1) are performed with the traceable parameter set (Lenton et al., 2006). The TII ensembles (Sect. 2.1.2) are performed using the LPC parameter set (Holden et al., 2010). The LPC averaged preindustrial surface air temperature (SAT) and Atlantic overturning stream function are reproduced in Fig. 2, together with ensemble standard deviations. The LPC ensemble exhibits a cold Antarctic bias, with Antarctic SAT $-31 \pm 10^{\circ} \mathrm{C}\left(\sim 10^{\circ} \mathrm{C}\right.$ cooler than NCEP data), likely a result of enforcing modern plausible sea-ice coverage; GENIE is known to underestimate Antarctic seaice (Lenton et al., 2006). The major shortcoming of ocean circulation in this configuration of GENIE is the failure of AABW to penetrate into the Atlantic sector (Lunt et al., 2006). However, the LPC parameter set has been designed to exhibit a wide range large-scale feedback strengths (see Sect. 2.1.2) that generally encompass the range of GCM responses to both LGM and $2 \times \mathrm{CO}_{2}$ forcing (Holden et al., 2010).

In both GENIE- 1 experiments, changing atmospheric $\mathrm{CO}_{2}$ is prescribed from ice core records (Luethi et al., 2008). Other greenhouse gases are neglected. We apply the orbital forcing of Berger (1978). Transient Laurentide and Eurasian Ice Sheets are represented by interpolating the spatial distribution of Ice-4G (Peltier, 1994) onto the benthic $\delta^{18} \mathrm{O}$ record
(Lisiecki and Raymo, 2005). We derive three variables for each grid cell representing (a) the threshold value $\delta^{18} \mathrm{O}_{\text {th }}$ at which the grid cell becomes ice covered, (b) the presentday orography $h_{0}$ and (c) the incremental orography $h_{1}$ at maximum attainable ice thickness. When $\delta^{18} \mathrm{O}>\delta^{18} \mathrm{O}_{\mathrm{th}}$, the height of the ice surface $h$ at each cell is given by the saturating relationship

$h=h_{0}+h_{1} \frac{\left(\delta^{18} \mathrm{O}-\delta^{18} \mathrm{O}_{\mathrm{th}}\right)}{\left(\delta^{18} \mathrm{O}-\delta^{18} \mathrm{O}_{\mathrm{th}}+k\right)}$

where $h_{1}$ is derived at each cell to give the Ice-4G height $h=h_{\mathrm{LGM}}$ when $\delta^{18} \mathrm{O}=\delta^{18} \mathrm{O}_{\mathrm{LGM}}$. The threshold for ice cover $\delta^{18} \mathrm{O}_{\text {th }}$ is derived from Ice- $4 \mathrm{G}$ reconstructions at $1 \mathrm{kyr}$ intervals from $21 \mathrm{kyr}$ BP to present. The constant $\mathrm{k}$ is fitted to approximate a linear relationship between global ice volume and $\delta^{18} \mathrm{O}$. The relationship in Eq. (1) is assumed to hold throughout the $800 \mathrm{kyr}$ record so that the value of $\delta^{18} \mathrm{O}$ at any point in time defines the spatial distribution and orography of the ice sheets globally. As the Greenland and Antarctic ice sheets are fixed at their preindustrial distributions in these simulations, the preindustrial ice sheet configuration arises whenever $\delta^{18} \mathrm{O} \leq 3.37 \%$ o (c.f. preindustrial $\delta^{18} \mathrm{O} \sim 3.2 \%$ ). This arises because $3.37 \%$ is the lowest threshold value ascribed to any grid cell, being the value of $\delta^{18} \mathrm{O}$ in the benthic stack at $7 \mathrm{kyr} \mathrm{BP}$ (the most recent time when no Laurentide 
or Eurasian Ice-4G ice remains). When $\delta^{18} \mathrm{O}>\delta^{18} \mathrm{O}_{\mathrm{LGM}}$, ice sheets are allowed to thicken (but not expand laterally) beyond the Ice-4G LGM configuration. This assumption leads to minimum sea-levels at $433 \mathrm{kyr}$ BP that are $6 \mathrm{~m}$ lower than at the LGM. We note that the only effects of sea-level change represented in GENIE-1 are on ocean salinity (and other ocean tracers when applicable).

Changing ice volume is translated into meltwater fluxes at each grid cell, routed to the Atlantic, Pacific and Arctic Oceans assuming modern topography. Accumulating ice is represented by reduced run-off. This ensures that freshwater fluxes are spatially and temporally consistent with the representation of the ice sheets, and avoids the problems associated with an unrealistic treatment of salt compensation which is responsible for much of the uncertainty in the far-field response to freshwater forcing (Stocker et al., 2007). Only the Laurentide and Eurasian Ice Sheets, which account for $\sim 80 \%$ of global ice-sheet change (Peltier, 2004), are allowed to change. This eliminates the potentially confounding effects of assuming synchronous Antarctic meltwater on ocean circulation; it is well known that millennial-scale Southern and Northern Hemisphere changes are likely to be out of phase (Blunier et al., 1998). A scaling of the freshwater flux (parameter "FFX", default value 1.5) is applied to correct for isostatic depression at the ice-bedrock interface (which we do not model) and for the assumption of a fixed land-sea mask; each of these simplifications would otherwise produce a $\sim 20 \%$ underestimation of ice-sheet volume.

The simulations apply an Atlantic-Pacific freshwater flux adjustment (parameter "APM") to correct for the $\sim 0.29 \mathrm{~Sv}$ underestimation of atmospheric moisture transport, required to maintain a stable Atlantic overturning (Edwards and Marsh, 2005). The flux adjustment is held constant during each transient simulation. GCM simulations suggest an uncertainty of $\pm 0.15 \mathrm{~Sv}$ in this flux, especially relevant to climate states that differ from modern (Zaucker and Broecker, 1992). However, although the neglect of atmospheric transport feedbacks quantitatively alters the modelled sensitivity to transient meltwater fluxes (Marsh et al., 2004), the ensemble is designed to cover the range of possible sensitivities, varying $\mathrm{APM}$ in the range 0.05 to $0.64 \mathrm{~Sv}$ across the LPC ensemble members.

\subsubsection{Transient GENIE-1 $800 \mathrm{kyr}$ simulations}

The climatology of the traceable parameter set used in the $800 \mathrm{kyr}$ simulations is discussed in detail elsewhere (Lenton et al., 2006). The equilibrium climate sensitivity of this parameterisation to a doubling of $\mathrm{CO}_{2}$ is $3.4^{\circ} \mathrm{C}$, slightly higher than the value of $3.2^{\circ} \mathrm{C}$ in the configuration of Lenton et al. (2006) due to the increased snow albedo feedback that arises from the inclusion of a lapse rate-related orography effect for temperature-driven surface processes. A lapse rate adjustment is not applied for atmospheric processes as these represent averages through the depth of the 1-layer atmo- sphere. Surface air temperature is thus calculated (and presented throughout) in terms of a sea-level equivalent. Two simulations are performed: $\mathrm{G}_{\mathrm{FW}}$, which includes the effects of glacial meltwater on ocean circulation $(\mathrm{FFX}=1.5)$, and $\mathrm{G}_{\mathrm{NFW}}$ which neglects this feedback $(\mathrm{FFX}=0)$.

\subsubsection{Transient GENIE-1 Termination II ensembles}

Three ensembles of transient simulations over TII (providing approximate analogues for TIII and TIV) are performed, differing in the boundary conditions applied in order to investigate uncertainties in forcing. Ensemble members are weakly constrained to produce plausible preindustrial and LGM climate states by applying the 480 member LPC parameter set, which varies 26 parameters over wide ranges (see Table 1 of Holden et al., 2010). The LPC parameters produce modern-plausible global average SAT, Atlantic overturning, Antarctic sea-ice coverage and land carbon storage, with distributions that are approximately centred on observations, and are additionally constrained to simulate plausible LGM Antarctic cooling (of $6-12^{\circ} \mathrm{C}$ ), though we note that glacial cooling of Antarctica may be overstated due to diffusive heat transport that is driven by cooling due to Northern Hemisphere ice sheets. The approach is designed to quantify model error by allowing parametric uncertainty to dominate over structural error. The ensemble members exhibit a wide range of ocean, atmospheric, sea-ice and vegetation feedback strengths which generally encompass the range of large-scale GCM responses to $2 \times \mathrm{CO}_{2}$ and LGM forcing, with a distribution for climate sensitivity of $3.8 \pm 0.6^{\circ} \mathrm{C}$ and for LGM globally averaged cooling of $5.9 \pm 1.2^{\circ} \mathrm{C}$ (c.f. $5.8 \pm 1.4{ }^{\circ} \mathrm{C}$, Schneider von Deimling et al., 2006).

The three ensembles are:

i) $E_{F W}$ which includes the impact of meltwater runoff on ocean circulation (Sect. 2.1) and allows for uncertainty in the strength of this feedback by varying FFX (in addition to 25 other parameters), uniformly distributed in the range 1 to 2 ,

ii) $\mathrm{E}_{\mathrm{NFW}}$ which neglects the role of meltwater $(\mathrm{FFX}=0$ in all ensemble members), and

iii) EWAIS which is identical to $E_{F W}$ except that the WAIS is replaced with land at sea level. Ice-sheet models (Pollard and DeConto, 2009) have simulated substantial WAIS retreat driven by sea-level rise at terminations (neglecting the additional bipolar forcing addressed here). Several lines of indirect evidence suggest that WAIS retreat contributed to the observed elevated sea levels during the last interglacial (Overpeck et al., 2006; Kopp et al., 2009). We capture the uncertainty associated with the degree and timing of potential WAIS retreat through the two extreme boundary conditions of $\mathrm{E}_{\mathrm{FW}}$ and $\mathrm{E}_{\mathrm{WAIS}}$. The modern WAIS comprises both marine-based and land-based ice. For consistency with the HadCM3 simulation (see Sect. 2.2), 
we assume the WAIS is removed and replaced entirely by ice-free land in the $\mathrm{E}_{\mathrm{WAIS}}$ ensemble. We note that replacing WAIS with ocean instead of land was found to simulate slightly higher peak Antarctic SAT anomalies $\left(2.8^{\circ} \mathrm{C}\right.$ c.f. $\left.2.2^{\circ} \mathrm{C}\right)$ in exploratory $650 \mathrm{kyr}$ transient GENIE-1 simulations not described here.

Melting of the WAIS, triggered by sea-level rise or local warming, would release meltwater to the southern ocean, potentially reducing convection and hence reducing local warming (Weaver et al., 2003; Swingedouw et al., 2009). Given the substantial uncertainties involved, however, we do not attempt to model this feedback in the present study. A hosing flux of $0.1 \mathrm{~Sv}$ into the Southern Ocean applied for 1000 years (equivalent in magnitude to the complete loss of WAIS ice in 650 years) simulated Antarctic SAT cooling of $\sim 0.5^{\circ} \mathrm{C}$ in the preindustrial climate state (Swingedouw et al., 2009). Transient Southern Ocean cooling events of this magnitude would not be inconsistent with "cooling rebounds" of up to $\sim 1^{\circ} \mathrm{C}$ that have been observed in several high southern latitude locations during the later stages of each of the last five terminations (Cortese et al., 2007, and references therein).

Transient $\mathrm{CO}_{2}$, orbit and ice sheets are applied as for the long simulations, except that the benthic $\delta^{18} \mathrm{O}$ record is linearised across the termination to produce an approximately constant $( \pm 20 \%)$ meltwater pulse, eliminating the oscillatory behaviour simulated during TII in the $800 \mathrm{kyr}$ simulation (see Fig. 1c). This oscillatory behaviour is not apparent in observations and is largely a consequence of translating the temporal signal in the gradient of benthic $\delta^{18} \mathrm{O}$ into global ice-sheet change. The temporal development of ice sheet volume (only Laurentide and Eurasian ice sheets contributions are considered here) and the resulting meltwater flux is illustrated in Fig. 3. As in the $800 \mathrm{kyr}$ simulation, meltwater is routed into the ocean assuming modern topography. The meltwater pulse commences at $135000 \mathrm{BP}$ and lasts for $\sim 7600$ years with an average of $\sim 0.11 \mathrm{~Sv}$, equivalent to $76 \mathrm{~m}$ sea level, but varying between ensemble members $(\sim 0.07$ to $0.15 \mathrm{~Sv}$ ) through the freshwater scaling parameter FFX. Simulations are spun-up to equilibrium at $135000 \mathrm{BP}$ and run for 11000 years.

\subsection{HadCM3 snapshot simulations}

The snapshot simulations are performed using the Hadley Centre coupled model HadCM3 (Gordon et al., 2000), a coupled atmosphere $\left(2.5^{\circ} \times 3.75^{\circ} \times 19\right.$ vertical levels $) /$ ocean $\left(1.25^{\circ} \times 1.25^{\circ} \times 20\right.$ vertical levels $)$ model which does not require flux adjustments to prevent climate drifts. Boundary conditions are $\left(\mathrm{H}_{\mathrm{PI}}\right)$ preindustrial, $\left(\mathrm{H}_{\mathrm{NFW}}\right) 130000 \mathrm{BP}$ orbit and greenhouse gases $\left(\mathrm{CO}_{2} 256 \mathrm{ppm}, \mathrm{CH}_{4} 506 \mathrm{ppb}\right.$, $\mathrm{N}_{2} \mathrm{O} 239 \mathrm{ppb}$ ) with modern ice sheets and no meltwater flux, $\left(\mathrm{H}_{\mathrm{FW}}\right)$ as $\mathrm{H}_{\mathrm{NFW}}$ with $1 \mathrm{~Sv}$ North Atlantic hosing (large enough to ensure collapse on timescales which can be practically simulated) and ( $\mathrm{H}_{\mathrm{WAIS}}$ ) as $\mathrm{H}_{\mathrm{FW}}$ with WAIS replaced

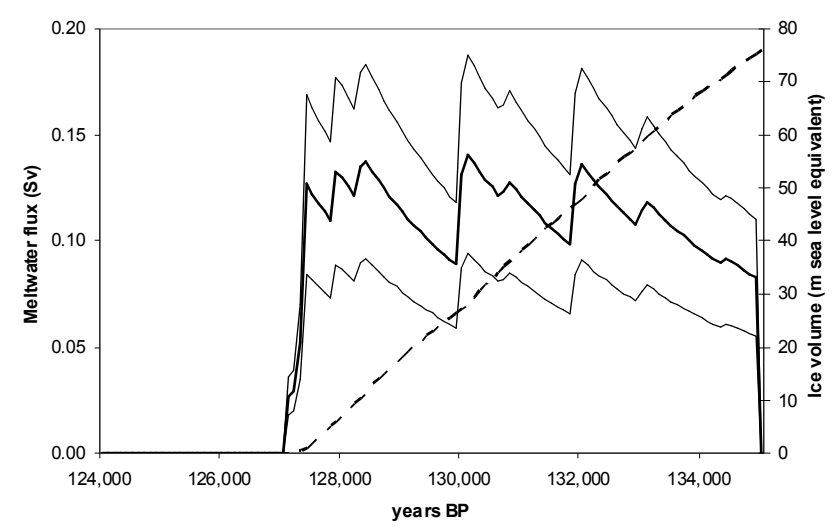

Fig. 3. Representation of ice sheets in the TII ensembles. The global distribution of ice sheets is given by Equation 1, assuming a constant reduction of $\delta^{18} \mathrm{O}$ from 4.86 to $3.16 \%$ from 135000 to $126000 \mathrm{BP}$. Meltwater is calculated at each grid cell and routed to the ocean assuming modern day topography. The dashed line illustrates total Laurentide and Eurasian ice sheet volume, expressed in equivalent meters of sea-level. The solid lines illustrates the profile of ensemble mean meltwater flux (bold, FFX $=1.5$ ) and the range of meltwater fluxes $(\mathrm{FFX}=1.0$ to FFX $=2.0)$. The temporal development of meltwater is fixed across all ensemble members.

entirely by ice-free land (at an elevation of $200 \mathrm{~m}$ ), in order to avoid ocean time-stepping instabilities which arise due to converging meridians near the pole (which are resolved with Fourier filtering at the North Pole). As noted above, in GENIE-1 simulations, replacing WAIS with ocean rather than land resulted in a modest increase in warming. Simulations are run for 200 years (from the modern spun-up state) and averaged over the last 30 years.

\section{Results}

\subsection{0 kyr GENIE-1 Transient Simulations}

Figure $1 \mathrm{~b}$ compares $800 \mathrm{kyr}$ records of i) modelled Antarctic SAT anomaly with DOME C (Jouzel et al., 2007) and ii) modelled SST anomaly (with a North Atlantic planktonic $\delta^{18} \mathrm{O}$ record (Venz et al., 1999) which we have mapped onto the LR04 timescale (Lisiecki and Raymo, 2005). Model data are from the simulation $\mathrm{G}_{\mathrm{FW}}$ (which includes meltwater forcing). We note the generally good agreement with both sets of observational data, with the exception of the marked failure to predict the existence of Antarctic WPTs. A similar discrepancy is not apparent in the North Atlantic record and we infer that WPTs are likely driven by an absent Southern Hemisphere forcing. MIS 7 is particularly interesting in this regard as the $\delta^{18} \mathrm{O}$ record suggest that substantial Northern Hemisphere ice sheets remained in place during this interglacial, so that temperatures $\sim 2{ }^{\circ} \mathrm{C}$ higher than preindustrial again suggest the WPT warming was localised to the Southern Hemisphere. For completeness we note that orbitally- 
forced summer warming is simulated at high northern latitudes during the Eemian, with maximum summer warming (averaged over all grid points north of $62^{\circ} \mathrm{N}$ ) peaking at $3.5^{\circ} \mathrm{C}$ in $126000 \mathrm{BP}$.

The first plot in Fig. 1c is the 350 kyr DOME F temperature record, reconstructed from $\delta^{18} \mathrm{O}$ and $\delta \mathrm{D}$ isotopic records, correcting for vapour source temperature and seawater isotopic composition variations (Kawamura et al., 2007). DOME $\mathrm{F}$ was chosen as it lies south of the Atlantic $\left(77^{\circ} \mathrm{S}\right.$, $39^{\circ} \mathrm{E}$ ) and may be expected to be more strongly influenced by AMOC changes than DOME C $\left(75^{\circ} \mathrm{S}, 123^{\circ} \mathrm{E}\right)$. In addition to the WPTs, and the warm spike in the early Holocene, three interstadials at DOME $\mathrm{F}$ are warmer than preindustrial at 317, 218 and $200 \mathrm{kyr}$ BP. These three interstadials are observed to be at least $\sim 1{ }^{\circ} \mathrm{C}$ cooler than preindustrial at DOME C (Fig. 1b), though we note that these apparent temperature differences between DOME C and DOME F may alternatively reflect spatial variations in the seasonality of precipitation in a warm Antarctica (Sime et al., 2009).

Antarctic SAT and SST meltwater anomalies $\left(\mathrm{G}_{\mathrm{FW}}-\mathrm{G}_{\mathrm{NFW}}\right.$, i.e. the differences in temperature when meltwater is imposed) are plotted in Fig. 1c and reflect the impact of meltwater on ocean circulation and heat transport. The SAT meltwater anomaly displays the millennial variability apparent in observations; the SST meltwater anomaly exhibits a similar temporal behaviour, though variability is suppressed by high-latitude sea ice during glacial periods. The SST meltwater spikes coincide very closely with spikes in isotopeinferred temperature. Late Pleistocene LR04 age-model uncertainty (the age model which defines the meltwater timing through the gradient of the benthic $\delta^{18} \mathrm{O}$ ) is estimated at $4 \mathrm{kyr}$ (Lisiecki and Raymo, 2005).

The timing of large scale meltwater spikes reflects large changes in $\delta^{18} \mathrm{O}$ and is likely to be robust (though subject to the aforementioned age-model uncertainties). However, this is not the case with respect to the detail and timing of the millennial variability, including that which is simulated during terminations. These features arise from variability in the gradient of the benthic $\delta^{18} \mathrm{O}$ signal, which translates into the meltwater fluxes. Although variability in ice-sheet melt rates presumably contributes to this signal, contributions also arise from a number of additional sources, notably including uncertainty in observational values of $\delta^{18} \mathrm{O} ; 1 \sigma$ errors of up to $\sim 0.1 \%$ o (Lisiecki and Raymo, 2005) are comparable to the average millennial decrease of $\sim 0.2 \%$ across a termination. The transient Antarctic SAT cooling of $\sim 1^{\circ} \mathrm{C}$ that occurs at the end of each termination (Fig. 1c) arises due to the positive Atlantic overturning cell extending further south during the reorganisation of the circulation at the end of the meltwater pulse. We note that in the ensemble analysis (Sect. 3.2) this transient cooling generally arises in those simulations in which the AMOC recovers. Amongst these 155 simulations, ensemble averaged cooling of $0.9 \pm 0.9^{\circ} \mathrm{C}$ occurs $1400 \pm 900$ years after the cessation of meltwater. This may not be a robust feature of the simulations, especially given the abrupt cessation of the forcing (Fig. 3). The cooling does not arise in the TII ensemble average (c.f. blue and pink curves in Fig. 4e), in part due to differences in the timing of these cooling events and in part due to the masking effect of the 19 simulations in which the AMOC does not recover and Antarctica remains warm.

\subsection{GENIE-1 ensembles of transient simulations over Termination II}

Although there is strong chronological similarity between observed and simulated warming, the magnitude of Antarctic SAT spikes in the single $800 \mathrm{kyr}$ simulation $\mathrm{G}_{\mathrm{FW}}\left(\sim 1.5^{\circ} \mathrm{C}\right.$, Fig. 1c and seen in Fig. 1b as small oscillations near the top of each simulated SAT rise) is insufficient to explain the observed warmings of $\sim 4{ }^{\circ} \mathrm{C}$ above present (Fig. 1b). Quantification of the discrepancy requires an assessment of modelling uncertainities; we apply an ensemble methodology to ascertain the most probable model response and quantify uncertainty.

The 480 meltwater-forced ensemble members $E_{\mathrm{FW}}$ universally exhibited weakened overturning during the termination (average weakening at $128000 \mathrm{BP}$ of $9 \pm 5 \mathrm{~Sv}$ with respect to preindustrial). Antarctic SAT at $128000 \mathrm{BP}$ is $>0.5^{\circ} \mathrm{C}$ warmer than preindustrial in 110 of these simulations, all of which exhibited a collapse of overturning (peak overturning $<6 \mathrm{~Sv}$ north of $44^{\circ} \mathrm{N}$ ), demonstrating that AMOC collapse is required for significant Antarctic warming in GENIE-1. We confine analysis to the 174 parameter sets with maximum overturning $<6 \mathrm{~Sv}$ to quantify the range of response.

Figure $4 \mathrm{a}$ illustrates the meltwater-forced SST anomaly at $128500 \mathrm{BP}\left(\mathrm{E}_{\mathrm{FW}}-\mathrm{E}_{\mathrm{NFW}}\right.$, i.e. the ensemble-averaged change in SST when meltwater is imposed) and displays the characteristic behaviour of the bipolar seesaw, although certain atmospheric feedbacks, such as the southward shift of the ITCZ, cannot be captured by the fixed-wind field EMBM. South of $62^{\circ} \mathrm{S}$, ensemble-averaged SST warming of $0.4 \pm 0.3{ }^{\circ} \mathrm{C}$ is simulated (uncertainties are expressed as $1 \sigma$ ensemble standard deviations throughout). Modern observations indicate that basal melt rates at the WAIS grounding line increase by $\sim 1 \mathrm{~m} \mathrm{yr}^{-1}$ for a $0.1^{\circ} \mathrm{C}$ increase in SST (Rignot and Jacobs, 2002), suggesting that the simulated warming may be significant for WAIS instability. Ice-sheet modelling has indicated that a $10 \mathrm{myr}^{-1}$ increase in Antarctic basal melt rates leads to sea level rise of $\sim 25 \mathrm{~cm}$ per century (Huybrechts and de Wolde, 1999). The ensemble design allows a wide range of sea-ice responses, with annual average Antarctic sea ice extent increasing by $9-15$ million $\mathrm{km}^{2}$ under LGM forcing and decreasing by $5-9$ million $\mathrm{km}^{2}$ under $2 \times \mathrm{CO}_{2}$ forcing (Holden et al., 2010). Meltwaterforced reduction in Antarctic sea-ice area at $128500 \mathrm{BP}$ is $2.7 \pm 1.6$ million $\mathrm{km}^{2}$. The simulated retreat of Antarctic sea ice is consistent with the southerly shift of productivity inferred from barium rain rates during MIS5.5 which can only be explained by a reduction in Antarctic sea ice (Nuern- 

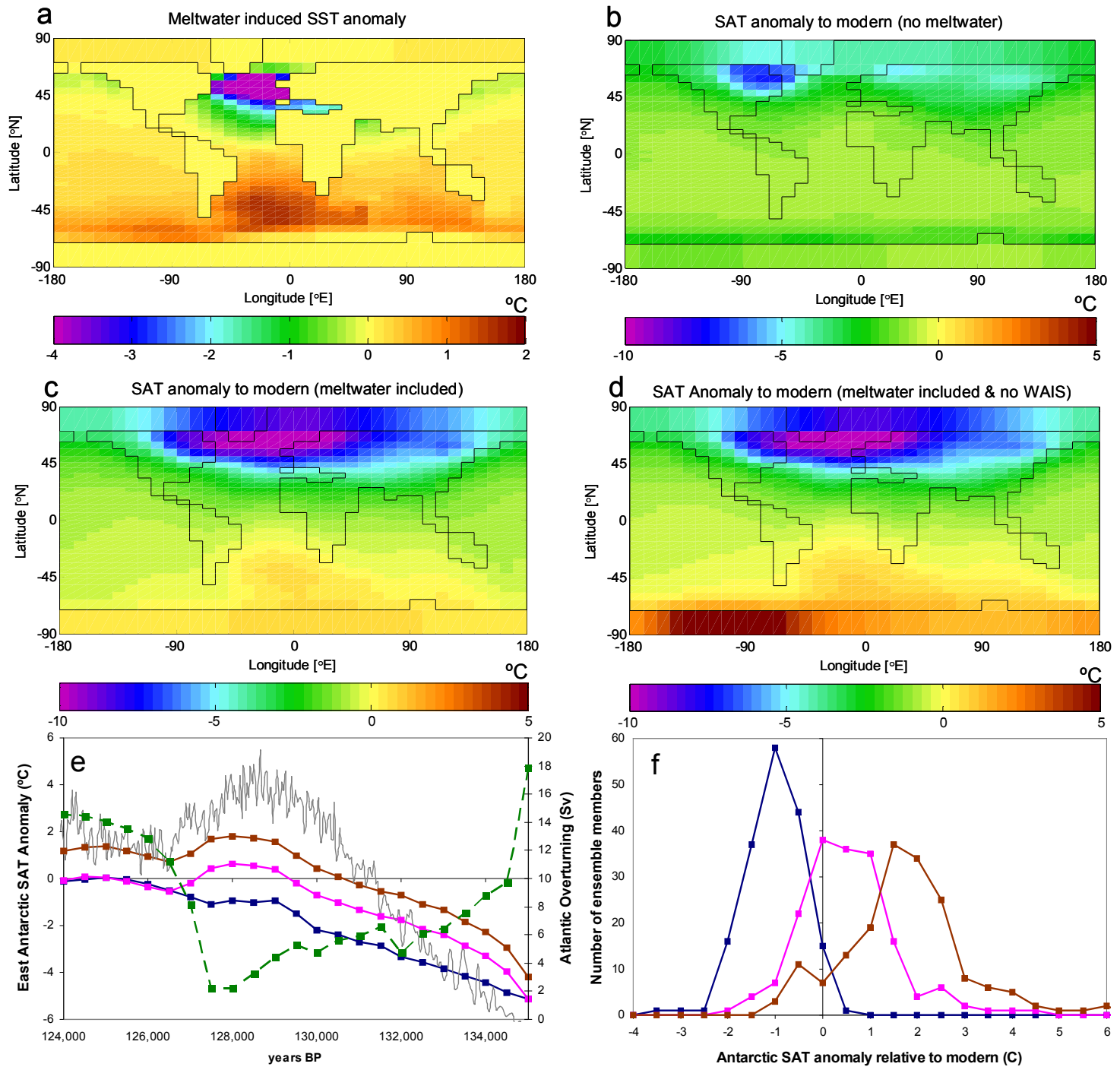

Fig. 4. GENIE-1 ensemble-averaged SST and SAT anomalies. Fields (at $128500 \mathrm{BP}$ ) of (a) meltwater induced SST anomaly (EFW$\mathrm{E}_{\mathrm{NFW}}$ ) and (b, c, d) SAT anomalies relative to an equilibrium preindustrial ensemble $\mathrm{E}_{\mathrm{PI}}$ with (b) no meltwater flux ( $\mathrm{E}_{\mathrm{NFW}}$ - $\mathrm{E}_{\mathrm{PI}}$ ), (c) including Laurentide and Eurasian meltwater fluxes $\left(\mathrm{E}_{\mathrm{FW}}-\mathrm{E}_{\mathrm{PI}}\right)$ and (d) including Laurentide and Eurasian meltwater fluxes and replacing West Antarctic Ice Sheet with land at sea-level (EWAIS-EPI). (e) Ensemble-averaged temporal behaviour of East Antarctic SAT anomaly. The dashed green line is the ensemble-averaged ( $\mathrm{E}_{\mathrm{FW}}$ ) Atlantic overturning (maximum streamfunction at depths below $400 \mathrm{~m}$ ). The grey line is the DOME C deuterium inferred anomaly (Jouzel et al., 2007). Solid lines are East Antarctic SAT anomalies with blue: no meltwater forcing $\left(\mathrm{E}_{\mathrm{NFW}}-\mathrm{E}_{\mathrm{PI}}\right)$, pink: meltwater forcing included $\left(\mathrm{E}_{\mathrm{FW}}-\mathrm{E}_{\mathrm{PI}}\right)$, brown: meltwater forcing included and WAIS removed to land at sea level (E EAIS-EPI). (f) Ensemble distributions of East Antarctic SAT anomaly at $128500 \mathrm{BP}$.

berg et al., 1997). The ensemble member with the largest meltwater-induced loss of annually-averaged Antarctic sea ice $\left(7.9\right.$ million $\left.\mathrm{km}^{2}\right)$ is associated with an East Antarctic SAT $2.4^{\circ} \mathrm{C}$ warmer than preindustrial, while the greatest East Antarctic warming, $4.7^{\circ} \mathrm{C}$ above preindustrial, is associated with the loss of 4.8 million $\mathrm{km}^{2}$ of Antarctic sea-ice. Thus the possibility that WPTs could be explained without a substantial WAIS retreat feedback appears unlikely (only six of the $174 \mathrm{E}_{\mathrm{FW}}$ simulations exhibit East Antarctic temperatures greater than $2.5^{\circ} \mathrm{C}$ above preindustrial), but cannot be ruled out.
Figure 4b-d illustrates ensemble-averaged SAT anomalies at $128500 \mathrm{BP}$ with respect to an equilibrium ensemble $\mathrm{E}_{\mathrm{PI}}$ forced with preindustrial boundary conditions. In the absence of meltwater forcing (Fig. 4b), East Antarctic SAT is $1.0 \pm 0.6^{\circ} \mathrm{C}$ cooler than preindustrial (despite slightly higher atmospheric $\mathrm{CO}_{2}$ concentrations of $\sim 285 \mathrm{ppm}$ ). This reflects a combination of global cooling due to the inferred remnant of the Laurentide ice sheet (which may be overstated in Antarctica due to the over-diffusive atmosphere) and lower Antarctic summer insolation; a single $800 \mathrm{kyr}$ transient simulation forced only with orbital changes pre- 
dicts annually averaged Antarctic temperatures $0.6^{\circ} \mathrm{C}$ below preindustrial at this time (ice sheets and atmospheric $\mathrm{CO}_{2}$ fixed at glacial conditions throughout). Meltwater forcing (Fig. 4c) increases East Antarctic SAT by $1.6 \pm 1.0^{\circ} \mathrm{C}$ (to $0.5 \pm 1.0^{\circ} \mathrm{C}$ warmer than preindustrial). In these simulations, the bipolar warming of Antarctica peaks in the Atlantic sector (i.e. in the vicinity of the forcing), with maximum warming at $\sim 15^{\circ} \mathrm{E}$ (Fig. $4 \mathrm{c}$ ), in the approximate vicinity of DOME F. This is qualitatively consistent with observations which indicate that interstadial temperatures may have been higher at DOME $F$ than at DOME C. The removal of WAIS (Fig. 4d) introduces further East Antarctic warming of $1.2 \pm 0.6^{\circ} \mathrm{C}$ (to $1.6 \pm 1.3^{\circ} \mathrm{C}$ warmer than preindustrial) arising from widespread loss of West Antarctic summer snow cover and reduced albedo. Within ensemble $\mathrm{E}_{\mathrm{WAIS}}, 39$ of the 174 simulations exhibit East Antarctic temperatures greater than $2.5^{\circ} \mathrm{C}$ above preindustrial.

Figure $4 \mathrm{e}$ summarises the temporal development of ensemble-averaged East Antarctic SAT under the three forcing scenarios. We do not regard WAIS retreat early in the termination as realistic; in the absence of a dynamic ice-sheet model we have simply assumed WAIS is absent throughout the $\mathrm{E}_{\mathrm{WAIS}}$ run, so the temporal behaviour would more reasonably be described by a transition from the $\mathrm{E}_{\mathrm{FW}}$ ensemble towards the EWAIS ensemble (implying a warming rate greater than either ensemble and hence closer to observations). Maximum overturning is also illustrated. In contrast to paleoclimatic evidence suggesting that glacial (LGM) overturning was weaker than today (McManus et al., 2004), GENIE-1 ensemble-averaged overturning is stronger in the glacial state. However, this change is of unclear sign, with 63 of the 174 simulations displaying a weakened overturning at $135000 \mathrm{BP}$ (ensemble average $0.9 \pm 2.6 \mathrm{~Sv}$ relative to preindustrial). The modelled resumption of overturning (commencing at $127500 \mathrm{BP}$ ) is within $\sim 1500$ years of the observed methane jump (commencing at 129000 BP, Fig. 1a), less than the $4 \mathrm{kyr}$ age model uncertainty of the benthic $\delta^{18} \mathrm{O}$ stack (Lisiecki and Raymo, 2005). We note that coral reef evidence indicates that the onset of Northern Hemisphere deglaciation occurred $\sim 4500$ years earlier (Thomas et al., 2009) than is suggested by a sea-level reconstruction derived from this benthic $\delta^{18} \mathrm{O}$ stack (Bintanja et al., 2005).

The $\mathrm{E}_{\mathrm{NFW}}$ ensemble distribution of East Antarctic SAT (Fig. 4f) illustrates that no point in our parameter space is capable of reconciling GENIE-1 with observations in the absence of substantial AMOC weakening (though we note that $\sim 10 \%$ of the simulations exhibit AMOC collapse in the absence of meltwater forcing). However, the two extreme boundary conditions represented by the distributions of $\mathrm{E}_{\mathrm{FW}}$ and EWAIS encompass the observational estimate of $\sim 4^{\circ} \mathrm{C}$ warming. Although we do not rule out the possibility that the bipolar seesaw could explain the discrepancy without a substantial WAIS feedback, we note that the observed East Antarctic warming of $\sim 2{ }^{\circ} \mathrm{C}$ which persists after the resumption of overturning can only be explained in the GENIE- 1 en- sembles with the assumption of some WAIS retreat (or alternatively with an overturning that remains weakened throughout the interglacial - the AMOC does not recover from its collapsed state in 19 of the 174 simulations).

\subsection{HadCM3 Eemian simulations}

In order to investigate the robustness of the GENIE-1 ensembles, in particular with regard to the simplified atmosphere and snow models, we performed four equilibrium HadCM3 simulations. Hosing induces AMOC collapse and results in statistically significant warming of $\sim 0.2-0.5^{\circ} \mathrm{C}$ in summer (DJF) SST in the Weddell and Ross Seas (Fig. 5a), accompanied by a reduction in Antarctic summer sea-ice extent and depth. A multi-model hosing ensemble $(0.1 \mathrm{~Sv}$, modern boundary conditions), performed to investigate inter-model uncertainty in response to hosing, also simulated warming in the Weddell Sea, apparently a consequence of enhanced deep convection and reduced sea ice (Stouffer et al., 2006).

In the absence of meltwater and ice-sheet forcing (Fig. 5b) HadCM3 fails to predict significant Antarctic SAT increase, though orbitally-forced summer warming of $3.0^{\circ} \mathrm{C}$ is simulated in Greenland. With freshwater hosing, precipitationweighted SAT (Fig. 5c) increases by $2.2^{\circ} \mathrm{C}$ at DOME F and $1.4^{\circ} \mathrm{C}$ at DOME $\mathrm{C}$, supporting GENIE-1 (annual-average East Antarctic warming of $1.6 \pm 1.0^{\circ} \mathrm{C}$ ). This warming is achieved after $\sim 100$ years of the 200 year simulation. The removal of WAIS (Fig. 5d) increases the precipitationweighted SAT anomaly to $4.9^{\circ} \mathrm{C}$ at DOME F and to $5.0^{\circ} \mathrm{C}$ at DOME C. Increased summer precipitation combines with greatest warming in summer when widespread West Antarctic snow melt is simulated. The $\mathrm{H}_{\mathrm{FW}}$ and $\mathrm{H}_{\mathrm{WAIS}}$ simulations encompass observed WPT warming. As the GENIE-1 ensemble parameterisations were designed to provide an unbiased estimate of the uncertainty associated with large-scale processes, $\mathrm{E}_{\mathrm{FW}}$ and $\mathrm{E}_{\mathrm{WAIS}}$ East Antarctic SAT variability of $\pm 1.0^{\circ} \mathrm{C}$ and $\pm 1.3^{\circ} \mathrm{C}$ provide indicative lower-bound measures of the parametric uncertainty in these single HadCM3 simulations.

\section{Discussion}

i) The $800 \mathrm{kyr}$ simulations demonstrate that GENIE-1, together with the imposed transient boundary conditions, is able to reproduce g-ig temperature change at the diverse locations of the Antarctic and the North Atlantic over 800000 years, effectively providing an extensive validation of modelled climate change for the full range of climate states and the entire period of the record. However, these simulations fail to reproduce Antarctic warmth that is significantly greater than present at any point in time, a failure which takes on a greater significance in view of the success of the model elsewhere in the record. Furthermore, the simulations demonstrate 

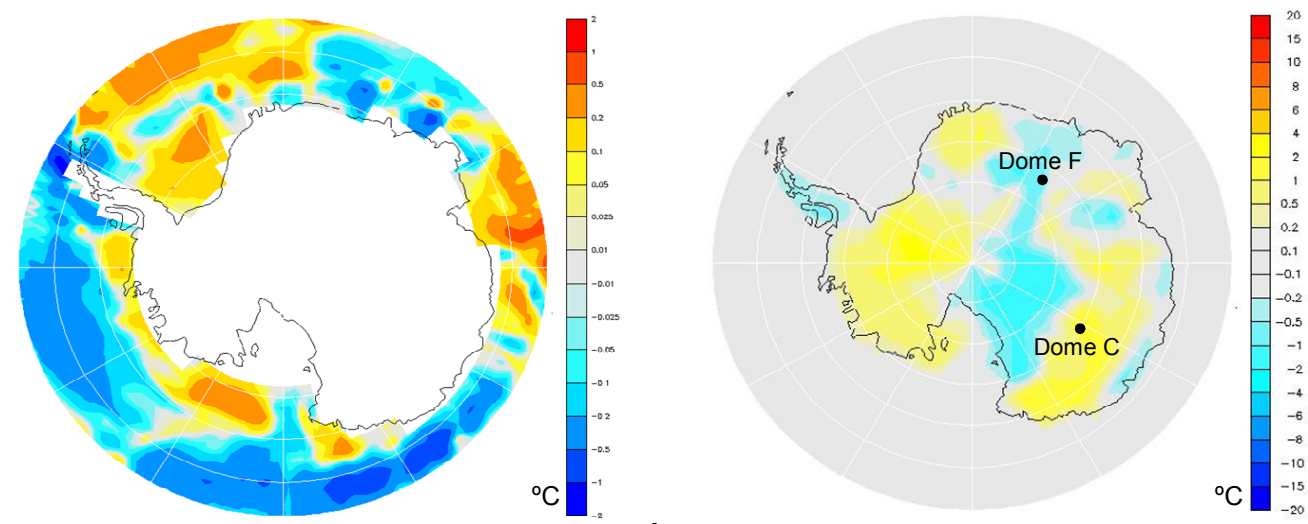

a

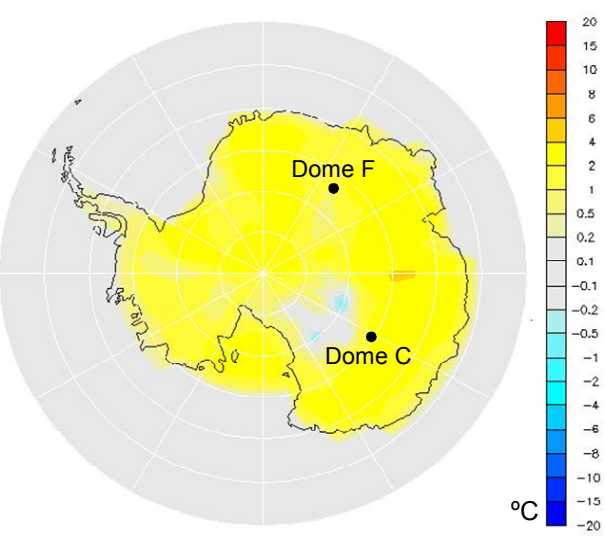

b

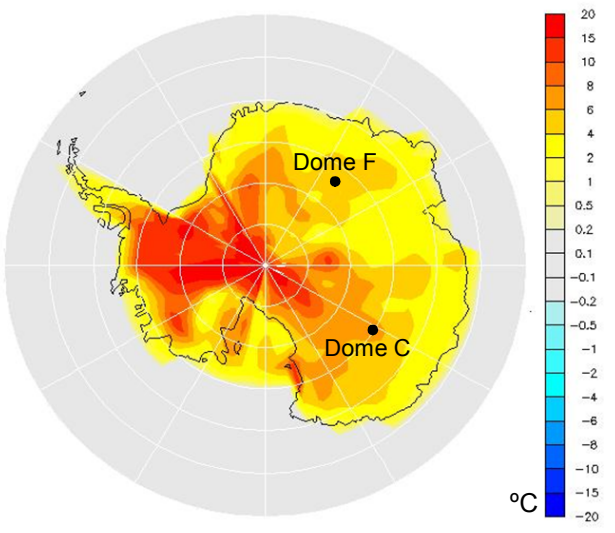

C

d

Fig. 5. HadCM3 SST and SAT anomalies at 130000 BP. (a) Southern summer freshwater-induced SST anomaly due to 1 Sv North Atlantic hosing applied uniformly between $50-70^{\circ} \mathrm{N}\left(\mathrm{H}_{\mathrm{FW}}-\mathrm{H}_{\mathrm{NFW}}\right)$. (b, c, d) Precipitation-weighted SAT anomalies relative to preindustrial (b) with no hosing $\left(\mathrm{H}_{\mathrm{NFW}}-\mathrm{H}_{\mathrm{PI}}\right)$, (c) including hosing $\left(\mathrm{H}_{\mathrm{FW}}-\mathrm{H}_{\mathrm{PI}}\right)$, (d) including hosing and with WAIS removed to land at $200 \mathrm{~m}\left(\mathrm{H}_{\mathrm{WAIS}}-\mathrm{H}_{\mathrm{PI}}\right)$.

substantial meltwater-forced WPTs $\left(\sim 1.5^{\circ} \mathrm{C}\right.$ in this single parameterisation) at times which coincide closely with observed transient warming. We note that the timing, magnitude and spatial distribution of the meltwater forcing is largely independent of the DOME F chronology (derived by tuning the $\mathrm{O}_{2} / \mathrm{N}_{2}$ ratio of trapped air bubbles to 21 December insolation at $77^{\circ} \mathrm{S}$ ); the meltwater forcing is derived from an interpolation of the spatial distribution of Ice-4G onto the benthic $\delta^{18} \mathrm{O}$ stack (with an age model derived from a simple ice model driven by 21 June insolation at $65^{\circ} \mathrm{N}$ ).

ii) The TII ensembles provide a quantification of the uncertainty that arises from structural, parametric and boundary condition sources. The meltwater-induced collapse of Atlantic overturning leads to simulated East Antarctic warming at $128500 \mathrm{BP}$ (of $1.6 \pm 1.0^{\circ} \mathrm{C}$ ) to $0.5 \pm 1.0^{\circ} \mathrm{C}$ above preindustrial. The ensemble averaged warming is consistent with Ganopolski and Roche (2009), who simulated $\sim 1^{\circ} \mathrm{C}$ and $2{ }^{\circ} \mathrm{C}$ warm- ing for hosing fluxes of 0.15 and $0.2 \mathrm{~Sv}$ respectively, although our ensemble design (varying 26 parameters simultaneously) does not facilitate a direct comparison with the qualitative differences which arise under different hosing assumptions due to increased "warmclimate" AMOC stability in their model (c.f. Ganopolski and Rahmstorf, 2001). The ensemble distribution of simulated warming does not appear sufficient to reproduce observations alone, although the tail of the distribution does encompass observations. We again note that absolute temperatures in Antarctica at this time (in all three GENIE-1 ensembles) may be understated due to diffusive heat transport that is driven by cooling due to Northern Hemisphere ice sheets in GENIE-1. The removal of WAIS increases ensemble-average East Antarctic temperature to $1.6 \pm 1.3^{\circ} \mathrm{C}$ above preindustrial. Thus, the inclusion of this feedback (even assuming the extreme of complete WAIS retreat) initially appears barely sufficient to explain East Antarctic warmth 
of $\sim 4{ }^{\circ} \mathrm{C}$ (although 39 of 174 simulations exhibit warming greater than $2.5^{\circ} \mathrm{C}$ above preindustrial); the full reconciliation requires consideration of precipitationweighted temperatures provided by the HadCM3 simulations.

iii) The precipitation-weighted temperatures from the HadCM3 simulations allow a full reconciliation with observations, although this agreement is clearly associated with considerable uncertainty arising from model (and observational) error sources and, notably, the degree of possible WAIS retreat. The HadCM3 hosing experiment (assuming modern WAIS) simulated precipitation-weighted temperatures in East Antarctica that are $\sim 2{ }^{\circ} \mathrm{C}$ warmer than preindustrial, consistent with GENIE-1 and likely insufficient to reconcile with observations alone. We note that although maximum warming is achieved after $\sim 100$ years in this experiment ( $1 \mathrm{~Sv}$ hosing is applied throughout the 200 year simulation), CCSM3 hosing experiments in the LGM state indicated that warming in Antarctica shows the strongest relationship with the duration of the forcing rather than either rate or total volume of freshwater (Otto-Bliesner and Brady, 2010), so the possibility of additional simulated warming under prolonged hosing cannot be ruled out. Furthermore, the 200 year integration neglects the transport of orbitally-driven warming of North Atlantic Deep Water to Circumpolar Deep Water (Duplessy et al., 2007) so that the simulated Antarctic temperature represents a lower bound. Cognisant of aforementioned uncertainties, the full reconciliation of HadCM3 with observations can be achieved under the assumption of WAIS retreat, with complete retreat producing precipitation-weighted temperature at both ice core sites $\left(\sim 5^{\circ} \mathrm{C}\right.$ above preindustrial $)$ that exceeds the generally accepted observed warming. The combination of extensive temporal and parametric investigations in GENIE-1 with detailed short-term integrations of HadCM3, and the agreement between the two models, substantially strengthens the conclusions that can be drawn from the experiments.

\section{Summary and conclusions}

In summary we have shown that GENIE-1 reproduces the temperature over Antarctica over the last 800 kyrs in a satisfactory way, with the notable exception of the last four interglacial periods. The three experiments we have performed, with GENIE-1 and HadCM3, together enable us to postulate that by including processes represented in both models and accounting for the statistical distribution of responses we could explain both the timing and magnitude of observations through the introduction of meltwater forcing during terminations, likely amplified by feedbacks resulting from WAIS retreat, though at present we are not able to achieve this in a single model. Although the tails of both meltwaterforced ensemble distributions ( $\mathrm{E}_{\mathrm{FW}}$ and $\mathrm{E}_{\mathrm{WAIS}}$ ) encompass observed WPT warming, reconciliation of data and modelling can only be readily achieved under the assumption of WAIS retreat. The combination of freshwater hosing and WAIS forcing produces precipitation-weighted temperatures $\sim 5^{\circ} \mathrm{C}$ above preindustrial in HadCM3. This warming arises from the combined effects of increased East Antarctic temperature and summer precipitation. We do not conclude that complete WAIS retreat is necessary to explain the model-data discrepancy, but have applied the extreme boundary conditions of modern and absent WAIS to span the possible range of the forcing associated with this feedback. We are not aware of other potential feedbacks that might explain $\sim 4{ }^{\circ} \mathrm{C}$ warming across East Antarctica.

Our simulations neglect possible convection feedbacks driven by WAIS meltwater which would be expected to reduce Antarctic temperature. The magnitude of this neglected feedback $\left(\sim 0.5^{\circ} \mathrm{C}\right.$ reduction in Antarctic SAT, c.f. Swingedouw et al., 2009) compares to ensemble-averaged Antarctic bipolar warming of $1.6 \pm 1.0^{\circ} \mathrm{C}$ (assuming no WAIS retreat). We note that the full magnitude of this feedback would imply a significant loss of WAIS ice. Assuming WAIS retreat would have occurred late in the termination, a feedback of this magnitude would not be inconsistent with "cooling rebounds" that are observed during the later stages of recent terminations (Cortese et al., 2007), though we note the possibility that such cooling events could alternatively be explained as a consequence of the reorganisation of the ocean circulation after the cessation of meltwater.

Several other points in the DOME F record are suggestive of a meltwater-forced bipolar signal, in particular the three anomalously warm interstadials which were apparently cooler at DOME C. During the previous three terminations, the bipolar seesaw would have warmed Antarctica throughout the deglaciation, with WAIS retreat occurring at some point, presumably late in the termination as interglacial conditions were approached. In contrast, the resumption of overturning during the $\mathrm{B} \varnothing l$ ling-Allerød/ACR cooled Antarctica towards the end of TI, potentially preventing further southern warming through stabilisation of the WAIS.

Acknowledgements. We would like to thank the three anonymous referees. Their careful and extensive comments have resulted in a much improved and clarified manuscript. This work was funded by the UK Natural Environment Research Council through QUEST-DESIRE (NE/E007600/1).

Edited by: V. Masson-Delmotte 


\section{References}

Barker, S., Diz, P., Vautravers, M. J., Pike, J., Knorr, G., Hall, I. R., and Broecker, W. S.: Interhemispheric Atlantic seesaw response during the last deglaciation, Nature, 457, 1097-1103, 2009.

Berger, A.: Long term variations of caloric insolation resulting from the Earth's orbital elements, Quaternary Res., 9, 139-167, 1978.

Bintanja, R., van de Wal, R. S. W., and Oerlemans, J.: Modelled atmospheric temperatures and global sea-levels over the past million years, Nature, 437, 125-128, 2005.

Blunier, T., Chappellaz, J., Schwander, J., Dällenbach, A., Stauffer, B., Stocker, T. F., Raynaud, D., Jouzel, J., Clausen, H. B., Hammer, C. U., and Johnsen, S. J.: Asynchrony of Antarctic and Greenland climate change during the last glacial period, Nature, 394, 739-743, 1998.

Carlson, A. E.: Why there was not a Younger Dryas-like event during the Penultimate Deglaciation, Quaternary Sci. Rev., 27, 882$887,2008$.

Cheng, H., Edwards, R. L., Wang, Y., Kong, X., Ming, Y., Kelly, M. J., Wang, X., Gallup, C. D., and Liu, W.: A penultimate glacial monsoon record from Hulu Cave and two-phase glacial terminations, Geology, 34, 217-220, 2006.

Cheng, H., Edwards, R. L., Broecker, W. S., Denton, G. H., Kong, X., Wang, Y., Zhang, R., and Wang, X.: Ice age terminations, Science, 326, 248-251, 2009.

Cortese, G., Abelmann, A., and Gersonde, R.: The last five glacialinterglacial transitions: a high resolution 450,000-year record from the subantarctic Atlantic, Paleoceanography, 22, PA4203, doi:10.1029/2007PA001457, 2007.

Dansgaard, W., Johnsen, S. J., Clausen, H. B., Dahl-Jensen, D., Gundestrup, N. S., Hammer, C. U., Hvldberg, C. S., Steffensen, J. P., Svelnbjörnsdottir, A. E., Jouzel, J., and Bond, G.: Evidence for general instability of past climate from a $250-\mathrm{kyr}$ ice-core record, Nature, 364, 218-220, 1993.

Delmotte, M., Chappellaz, J., Brook, E., Yiou, P., Barnola, J. M., Goujon, C., Raynaud, D., and Lipenkov, V. I.: Atmospheric methane during the last four glacial-interglacial cycles: rapid changes and their link with Antarctic temperature, J. Geophys. Res., 109, D12104, doi:10.1029/2003JD004417, 2004.

Duplessy, J. C., Roche, D. M., and Kageyama, M.: The deep ocean during the last interglacial period, Science, 316, 89-91, 2007.

Edwards, N. R. and Marsh, R.: Uncertainties due to transportparameter sensitivity in an efficient 3-D ocean-climate model, Clim. Dynam., 24, 415-433, 2005.

Ganopolski, A. and Rahmstorf, S.: Rapid changes of glacial climate simulated in a coupled climate model, Nature, 409, 153158, 2001.

Ganopolski, A. and Roche, D.: On the nature of lead-lag relationships during glacial-interglacial climate transitions, Quaternary Sci. Rev., 28, 3361-3378, 2009.

Gordon, C., Cooper, C., Senior, C. A., Banks, H., Gregory, J. M., Johns, T. C., Mitchell, J. F. B., and Wood, R. A.: The simulation of SST, sea ice extents and ocean heat transports in a version of the Hadley Centre coupled model without flux adjustments, Clim. Dynam., 16, 147-168, 2000.

Groll, N., Widmann, M., Jones, J. M., Kaspar, F., and Lorenz, S. J.: Simulated relationships between regional temperatures and large-scale circulation: $125 \mathrm{kyr} \mathrm{BP}$ (Eemian) and the preindustrial period, J. Climate, 18, 4032-4045, 2005.

Holden, P. B., Edwards, N. R., Oliver, K. I. C., Lenton, T. M., and
Wilkinson, R. D.: A probabilistic calibration of climate sensitivity and terrestrial carbon change in GENIE-1, Clim. Dynam., doi:10.1007/s00382-009-0630-8, in press, 2010.

Huybrechts, P. and de Wolde, J.: The dynamic response of the Greenland and Antarctic ice sheets to multiple-century climate warming, J. Climate, 8, 2169-2188, 1999.

Jouzel, J., Masson-Delmotte, V., Cattani, O., Dreyfus, G., Falourd, S., Hoffman, G., Minster, B., Nouet, J., Barnola, J. M., Chappellaz, J., Fischer, H., Gallet, J. G., Johnsen, S., Leuenberger, M., Loulergue, L., Luethi, D., Oerter, H., Parrenin, F., Raisbeck, G., Raynaud, D., Schilt, A., Schwander, J., Selmo, E., Souchez, R., Spahni, R., Stauffer, B., Steffensen, J. P., Stenni, B., Stocker, T. F., Tison, J. L., Werner, M., and Wolff, E. W.: Orbital and Millennial Antarctic climate variability over the past 800000 years, Science, 317, 793-796, 2007.

Kawamura, K., Parrenin, F., Lisiecki, L. Uemura, R., Vimeux, F., Severinghaus, J. P., Hutterli, M. A., Nakazawa, T., Aoki, S., Jouzel, J., Raymo, M., Matsumoto, K., Nakata, H., Motoyama, H., Fujita, S., Goto-Azuma, K., Fujii, Y., and Watanabe, O.: Northern Hemisphere forcing of climatic cycles in Antarctica over the past 360,000 years, Nature, 448, 912-916, 2007.

Kelly, M. J., Edawrds, R. L., Cheng, H., Yuan, D., Cai, Y., Zhang, M., Lin, Y., An, Z.: High resolution characterisation of the Asian Monsoon between 146,000 and 99,000 years B.P. from Donge Cave, China and global correlation of events surrounding Termination II, Palaeogeogr. Palaeocl., 236, 20-38, 2006.

Kopp, R. E., Simons, F. J., Mitrovica, J. X., Maloof A. C., and Oppenheimer, M.: Probabilistic assessment of sea level during the last interglacial stage, Nature, 462, 863-868, 2009.

Lenton, T. M., Williamson, M. S., Edwards, N. R., Marsh, R., Price, A. R., Ridgwell, A. J., Shepherd, J. G., Cox, S. J., and The GENIE team: Millennial timescale carbon cycle and climate change in an efficient Earth system model, Clim. Dynam., 26, 687-711, 2006.

Lisiecki, L. E. and Raymo, M. E.: A Pliocene-Pleistocene stack of 57 globally distributed benthic $\delta^{18} \mathrm{O}$ records, Paleoceanography, 20, PA1003, doi:10.1029/2004PA001071, 2005.

Loulergue, L., Schilt, A., Spahni, R., Masson-Delmotte, V., Blunier, T., Lemieux, B., Barnola, J.-M., Raynaud, D., Stocker, T. F., and Chappellaz, J. M.: Orbital and millennial scale features of atmospheric $\mathrm{CH}_{4}$ over the last 800,000 years, Nature, 453, 383-386, 2008.

Luethi, D., Le Floch, M., Bereiter, B., Bluner, T., Barnola, J.-M., Siegenthaler, U., Raynaud, D., Jouzel, J., Fischer, H., Kawamura, K., and Stocker, T. F.: High-resolution carbon dioxide concentration record 650,000-800,000 years before present, Nature, 453, 379-382, 2008.

Lunt, D. J., Williamson, M. S., Valdes, P. J., Lenton, T. M., and Marsh, R.: Comparing transient, accelerated, and equilibrium simulations of the last 30,000 years with the GENIE- 1 model, Clim. Past, 2, 221-235, doi:10.5194/cp-2-221-2006, 2006.

Marsh, R., Yool, A., Lenton, T. M., Gulamali, M. Y., Edwards, N. R., Shepherd, J. G., Krznaric, M., Newhouse, S., and Cox, S. J.: Bistability of the thermohaline circulation identified through comprehensive 2-parameter sweeps of an efficient climate model, Clim. Dynam., 23, 761-777, 2004.

Masson-Delmotte, V., Stenni, B., Pol, K., Braconnot, P., Cattani, O., Falourd, S., Kageyama, M., Jouzel, J., Landais, A., Minster, B., Barnola, J. M., Chappellaz, J., Krinner, G., 
Johnsen, S., Röthlisberger, R., Hansen, J., Mikolajewicz, U., and Otto-Bliesener, B.: EPICA Dome $\mathrm{C}$ record of glacial and interglacial intensities, Quaternary Sci. Rev., 29, 113-128, doi:10.1016/j.quascirev.2009.09.030, 2010.

McManus, J. F, Oppo, D. W., and Cullen, J. L.: A 0.5 million year record of millennial-scale climate variability in the North Atlantic, Science, 283, 971-976, 1999.

McManus, J. F., Francois, R., Gherardi, J.-M., Keigwin, L. D., and Brown-Leger, S.: Collapse and rapid resumption of Atlantic meridional circulation linked to deglacial climate changes, Nature, 428, 834-837, 2004.

Montoya, M., von Storch, H., and Crowley, T. J.: Climate simulation for $125 \mathrm{kyr} \mathrm{BP}$ with a coupled ocean-atmosphere general circulation model, J. Climate, 13, 1057-1072, 2000.

Nuernberg, C. C., Bohrmann, G., and Schlueter, M.: Barium accumulation in the Atlantic sector of the Southern Ocean: results from 190,000 year records, Paleoceanography, 12, 594603, 1997.

Otto-Bliesner, B. L., Marshall, S. J., Overpeck, J. T., Miller, G. H., $\mathrm{Hu}$, A., and CAPE Last Interglacial Project Members: Simulating Arctic climate warmth and icefield retreat in the last interglaciation, Science, 311, 1751-1753, 2006.

Otto-Bliesner, B. L. and Brady, E. C.: The sensitivity of the climate response to the magnitude and location of freshwater forcing: last glacial maximum experiments, Quaternary Sci. Rev., 29, 5673, 2010.

Overpeck, J. T., Otto-Bliesner, B. L., Miller, G. H., Muhs, D. R., Alley, R. B., and Kiehl, J. T.: Paleoclimatic evidence for future ice-sheet instability and rapid sea-level rise, Science, 311, 17471750, 2006.

Peltier, W. R.: Ice age paleotopography, Science, 265, 195-201, 1994.

Peltier, W. R.: Global glacial isostasy and the surface of the ice-age earth: the ICE-5G (VM2) model and GRACE, Annu. Rev. Earth Pl. Sc., 32, 111-149, 2004.

Pollard, D. and DeConto, R. M.: Obliquity-paced Pliocene West Antarctic ice sheet oscillations, Nature, 457, 329-333, 2009.

Rignot, E. and Jacobs, S. S.: Rapid bottom melting widespread near Antarctic ice sheet grounding lines, Science, 296, 2020-2023, 2002.

Rougier, J.: Probabilistic inference for future climate using an ensemble of climate model evaluations, Clim. Change, 81, 247264, 2007.

Schneider von Deimling, T., Ganopolsky, A., Held, H., and Rahmstorf, S.: How cold was the last glacial maximum, Geophys. Res. Lett., 33, L14709, doi:10.1029/2006GL026484, 2006.
Sime, L. C., Wolff, E. W., Oliver, K. I. C., and Tindall, J. C.: Evidence for warmer interglacials in East Antarctic ice cores, Nature, 462, 342-345, 2009.

Stocker, T. F. and Johnsen, S. F.: A minimum thermodynamic model for the bipolar seesaw, Paleoceanography, 18, 1087, doi:10.1029/2003PA000920, 2003.

Stocker, T. F., Timmermann, A., Renold, M., and Timm, O.: Effects of salt compensation on the climate model response in simulations of large changes of the Atlantic Meridional Overturning Circulation, J. Climate, 20, 5912-5928, 2007.

Stouffer, R. J., Yin, J., Gregory, J. M., Dixon, K. W., Spelman, M. J., Hurlin, W., Weaver, A. J., Eby, M., Flato, G. M., Hasumi, H., Hu, A., Jungclaus, J. H., Kamenkovich, I. V., Levermann, A., Montoya, M., Murakami, S., Nawrath, S., Oka, A., Peltier, W. R., Robitaille, D. Y., Sokolev, A., Vettoretti, G., and Weber, S. L.: Investigating the causes of the response of the thermohaline circulation to past and future climate changes, J. Climate, 19, 1365-1387, 2006.

Swingedouw, D., Fichefet, T., Goosse, H., and Loutre, M. F.: Impact of transient freshwater releases in the Southern Ocean on the AMOC and climate, Clim. Dynam., 33, 365-381, 2009.

Thomas, A. L., Henderson, G. M., Deschamps, P., Yokoyama, Y., Mason, A. J., Bard, E., Hamelin, B., Durand, N., and Camoin, G.: Penultimate deglacial sea-level timing from uranium/thorium dating of Tahitian corals, Science, 324, 1186-1189, 2009.

Venz, K. A., Hodell, D. A., Stanton C., and Warnke D. A.: A 1.0 Myr record of Glacial North Atlantic Intermediate Water variability from ODP site 982 in the northeast Atlantic, Paleoceanography, 14, 42-52, 1999.

Wang, Y. J., Cheng, H., Edwards, R. L., An, Z. S., Wu, J. Y., Shen, C.-C., and Dorale, J. A.: A high-resolution absolute dated Late Pleistocene monsoon record from Hulu Cave, China, Science, 294, 2345-2348, 2001.

Weaver, A. J., Saenko, O. A., Clark, P. U., and Mitrovica, J. X.: Meltwater Pulse 1A from Antarctica as a trigger of the BøllingAllerød warm interval, Science, 299, 1709-1713, 2003.

Williamson, M. S., Lenton, T. M., Shepherd, J. G., and Edwards, N. R.: An efficient terrestrial scheme (ENTS) for Earth system modelling, Ecol. Model, 198, 362-374, 2006.

Wolff, E. W., Fischer, H., and Röthlisberger, R.: Glacial terminations as southern warmings without northern control, Nat. Geosci., 2, 206-209, 2009.

Zaucker, F. and Broecker, W. S.: The influence of atmospheric moisture transport on the freshwater balance of the Atlantic drainage basin: general circulation model simulations and observations, J. Geophys. Res., 97, 2765-2773, 1992. 